\title{
Growth Kinetics of Vegetative and Reproductive Organs of Guava (Psidium guajava L.) in Iguala Guerrero, Mexico
}

\author{
Agustín Damián Nava, Víctor A. González Hernández², Manuel Nava Jaimes, \\ Elías Hernández Castro ${ }^{1 *}$, Dolores Vargas Álvarez ${ }^{1}$, Gemima Díaz Villaseñor ${ }^{1}$, \\ Francisco Palemón Alberto' ${ }^{1}$, Blas Cruz Lagunas ${ }^{1}$ \\ ${ }^{1}$ Academic Unit of Agricultural and Environmental Sciences, The Autonomous University of Guerrero, \\ Guerrero, México \\ ${ }^{2}$ Institute of Genetic Resources and Productivity, Graduate College, Texcoco, Mexico \\ Email: ${ }^{*}$ ehernandezcastro@yahoo.com.mx
}

Received 3 September 2014; revised 14 October 2014; accepted 4 November 2014

Copyright (C) 2014 by authors and Scientific Research Publishing Inc.

This work is licensed under the Creative Commons Attribution International License (CC BY).

http://creativecommons.org/licenses/by/4.0/

(c) (i) Open Access

\section{Abstract}

In the Mexican tropics the guava trees can grow and produce in any season, so they can be harvested out of the period of high competition marketing (Summer). It studied the growth kinetics of leaves and fruits of guava trees at the dry tropical conditions of the State of Guerrero, in guava trees of four years old and was evaluated a non-destructive method for measuring leaf area from November to May. 100 sheets of 10 randomly selected trees were cut. It was found that leaf length $X$ the width $X 0.72581647$ (conversion factor) gave an estimated leaf area which was significantly correlated with that obtained by the integrator of leaf area. Both in length and width the leaf growth kinetics were sigmoid with three growth stages: In Stage I (15 days) leaves grew $21.2 \%$ and 21.5\%; in Stage II (26 days) grew 73.6\% and 68\%; and in Stage III (30 days). They Increased 5.2\% and $10.5 \%$ in the primary and secondary sprouts. The fruit growth in its equatorial and polar diameters corresponded to a double sigmoid kinetics. In Stage I (61 days) it reached 1.9 and $2.3 \mathrm{~cm}$; in Stage II (62 - 102 days) it reached 3.09 and $3.62 \mathrm{~cm}$; and in Stage III (103 to 126 days) it reached 4.63 and $5.13 \mathrm{~cm}$, as well as the physiological maturity of fruit.

\section{Keywords}

Psidium guajava, Growth Kinetics, Phenological Events

\footnotetext{
${ }^{*}$ Corresponding author.
}

How to cite this paper: Nava, A.D., et al. (2014) Growth Kinetics of Vegetative and Reproductive Organs of Guava (Psidium guajava L.) in Iguala Guerrero, Mexico. Agricultural Sciences, 5, 1468-1475. 


\section{Introduction}

Globally, India is the most important in the production of guava with 1.8 million tons annually grown on 150,000 ha. Mexico ranks second with a production volume of more than 300,000 tones, spread over 23,900 ha are grown in 19 states, of which protrude Aguascalientes, Michoacán and Zacatecas with 21,000 ha, representing 88\% of the total area [1]. The guava is produced in the states of Aguascalientes and Zacatecas (region called Calvillo Cannons) and is considered the best quality for fresh consume, because of its aroma, flavor and consistency [2].

In Iguala, Guerrero, guava vegetative buds form during most of the year, although higher flows are in July, September and January. Along with the formation of buds, floral development occurs, so there is also formation of flowers for most of the year. But the main fruiting begins in winter, so that fruit production is in summer [3].

In Maracaibo, Venezuela, the time between the mooring of the fruit (flowers with stamens withered) and ripening (yellow skin fruit and good consistency) from 121 days to 114 days after lashing the fruit begins to change from green pale yellow one [4].

The rate of ripening of guava Red Creole type and San Miguel in Mara, Zulia, Venezuela, reflects that during this process the fruit shows changes in color, ranging from green to yellow due to pigments such as flavones, anthocyanins and carotenoids providing secondary colors, on a primary color, green or yellow generally determined by the presence of chlorophyll or xanthophyll [5].

Studying the behavior of plants should be performed based on the phenomena of weather, that through this basic knowledge, defined rational handling of crops; also, consider nutrition and pesticide application, depending on the requirements and the phenological stages of the plant [6].

One of the main problems in the production of guava in Mexico is that the harvest is concentrated in summerautumn, causing reduction in the price of fruit. Because of this we should take advantage of the plasticity of guava to vegetate and produce at any time of the year in order to get the crop out of the period of increased competition [3]. As this requires knowing the plant phenology, this study aimed to determine the kinetics of growth of vegetative and reproductive organs of guava, so that through this knowledge can improve the agronomic management of the crop.

\section{Materials and Methods}

\subsection{Location, Soil and Climatic Conditions and Crop Management}

The study was done in Iguala, Guerrero, Mexico, located at the geographical coordinates $18^{\circ} 20^{\prime} 37.4^{\prime \prime} \mathrm{LN}$ and $99^{\circ} 30^{\prime} 06.8 " \mathrm{LW}$, at an altitude of $771 \mathrm{~m}$ (GPS Garmin eTrex $10^{\circledR}$ ). The climate is Awo (W) (i') g, the driest of the sub-humid, with average annual temperature of $25.5^{\circ} \mathrm{C}$ and average annual rainfall of $1067 \mathrm{~mm}$, with rainfall in summer (June to September) and presence of intermission drought in July and August [7]. The site soil is deep dark brown, $\mathrm{pH}$ 8.2, 40\% clay, 1.5\% organic matter, $0.3 \%$ total N, $15 \mathrm{mg} \cdot \mathrm{kg}^{-1}$ of P and $\mathrm{K}$ than $2 \mathrm{cmol} \cdot \mathrm{kg}^{-1} \mathrm{soil}$ [8].

The trees selected had four years of age; propagated from air-layers; acquired in Coatepec, Flours, State of Mexico. The trees was gravity irrigation applied, from November to April, in intervals of 20 days; no edaphic and foliar fertilizer; no pruning was performed; hand weeding is performed. Regarding phytosanitary problems, was presented only the fruit fly (Anastrepha spp.), it was controlled with weekly applications of Malathion $1000^{\circledR}\left(2 \mathrm{ml} \cdot \mathrm{L}^{-1}\right.$ water); during the period from August to December (fruit set to harvest).

The period of evaluation was conducted in November 2011 to May 2012. The crop irrigation was applied from November 30 to April 30, at interval of 20 days, no was done pruning and not fertilizer appli. The fruit fly (Anastrepha spp.) Was monitored weekly applications of Malathion $1000^{\circledR}$ ( $2 \mathrm{~mL} \cdot \mathrm{Liter}^{-1}$ of water).

\subsection{Methodology}

To observe the kinetics of growth was measured daily center width and length of the leaf 10 and five leaves/shoot primary and secondary respectively, reaching constant values throughout (physiological maturity).

To determine the leaf area of 10 trees measured the length and width (in cm) of 100 leaves taken at random and each of these leaves was determined the area integrator LI-3100 leaf area (Licor, Inc.). For the analysis of the data, was made analysis of variance, comparison of means by Tukey test, Pearson correlation and regression coefficient; using the values of length, width, length X width leaves and leaf area registered with integrator LI-3100 (Licor, Inc.). With the values obtained, the conversion factor was calculated and multiplied by the length, width and length $\mathrm{X}$ width of 10 leaves of six primary shoots and five leaves of six secondary shoots; the value obtained was 
compared to the leaf area obtained through the integrator Ll-3100. All the analyses were performed using SAS package (Statistical Analysis System, Version 8.00) [9].

For fruit growth kinetics of four trees were measured daily 10 fruits/tree recently tied regarding equatorial diameter (ED) and polar diameter (DP), until they reached physiological maturity and consume. Physiological maturity was considered when the fruit changed from green to green-yellow, and consume when switched completely green-yellow to yellow. The values obtained were the result of the average of the 10 fruits of each tree and finally the average of the four trees. The data analysis was to estimate the program averages Excel, Version 2000.

\section{Results and Discussion}

\subsection{Growth in Length and Width of Leaf}

The leaf growth rate showed a sigmoid curve length and width of leaves of primary and secondary shoots (Figure 1).

The newly formed leaves of primary and secondary shoots averaged 0.8 and $0.2 \mathrm{~cm}$ in length and width, respectively, but to reach its maximum size median 11.1 and $11.4 \mathrm{~cm}$ long and 5.1 to $5.2 \mathrm{~cm}$ wide. These leaf dimensions are within the ranges presented guava leaves of the town of Calvillo, Aguascalientes (place of origin of the genetic material of the present study), ranging from $5-18 \mathrm{~cm}$ long and 3 to $6.5 \mathrm{~cm}$ wide [10].

This regional germplasm presents morphological and biochemical high variability between and within orchards producing because they spread by seed and root suckers [2]. The leaves, to reach their maximum length and width, they need 70 to 63 days for primary and secondary buds. Upon completion of growth, stresses that guava leaves remain on the tree about 90 to 100 days, in both types of buds. The sigmoid kinetics of growth in length and width of leaves in both types of buds, showed three stages: I, which included the first 15 days, the II for 16 - 41 days, and the III from 42 to 71 days for the leaves reach physiological maturity. The importance of understanding these stages is that when the leaves are in Stages I and II (young leaves still expanding) have low photosynthetic capacity, but this increased progressively with age until the leaf has grown from $70 \%$ to $100 \%$ of its maximum size that is when also reaches its maximum net photosynthetic rate [11] and [12]. After leaf photosynthesis gradually decreases to become senescent, when unable to photosynthesize due to chlorophyll degradation and loss of functional chloroplasts [12].

\subsection{Determination of the Conversion Factor for the Calculation of Leaf Area by Length, Width and Leaf Length X Width}

To calculate leaf area was determined a regression coefficient between the value of length, width or length $X$ width, with the value of the leaf area integrator. It was found that when using the long blade width $\mathrm{X}$ multiplied by its conversion factor ( 0.72581647$)$, leaf area is very similar to that obtained by integrating the leaf area this aspect is important because it allows to estimate the leaf area without expensive equipment and because the characteristics of the leaves are those that best explain the phenotypic variability of guava trees [2].

Instead, by using the value of length of the blades multiplied by the conversion factor (4.96351652), the estimated area is greater than $15 \mathrm{~cm}^{2}$ leaf areas directly measure the integrator, likewise, the area estimated by width product leaves its conversion factor (10.4234197), is greater in $13 \mathrm{~cm}^{2}$ leaf area of the integrator (Figure 2). Therefore, it is suggested that to determine the leaf area of the leaves of guava simply multiply the length by width of the leaves for its conversion factor (0.72581647).

To confirm and support the results of the regression coefficient, were performed two types of analysis, one of variance and Pearson correlation, finding highly significant differences in the four variables assessed in the leaves of guava cv. "average Chinese" in the analysis of variance (Table 1).

And in analyzing the Pearson correlation the effect was highly significant in the four variables measured in the 10 guava trees, cv. "average Chinese" (Table 2).

\subsection{Calculation of Primary Shoots Leaf Area through the Conversion Factor}

Once the best conversion factor to estimate the area of each leaf was calculated the individual leaf area of each leaf. This was taken into account that the guava tree formed an average of 20 leaves per bud new primary, of which during the sampling period just 10 reached physiological maturity to these 10 leaves were taken individually their long and wide, and thus calculated the length $\mathrm{X}$ width product. A similar procedure was used to estimate leaf area with length and width values of each sheet by multiplying their respective conversion factors (4.96351652 for 


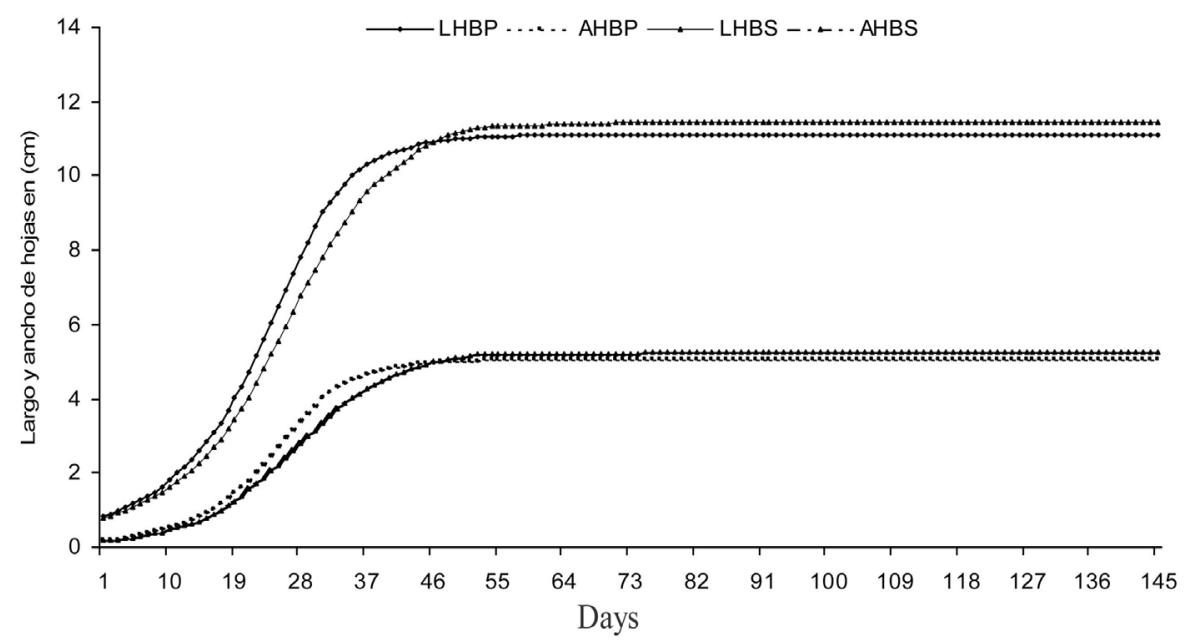

Figure 1. Kinetics of growth in length and width (in $\mathrm{cm}$ ) of 60 and 30 leaves of guava in primary and secondary outbreaks respectively, in the period November to May in Iguala, Gro. LHBP = Length of primary shoot leaves; AHBP = Width primary outbreak leaves; LHBs = Length of secondary outbreak leaves; AHBS = Width of secondary sprout leaves.

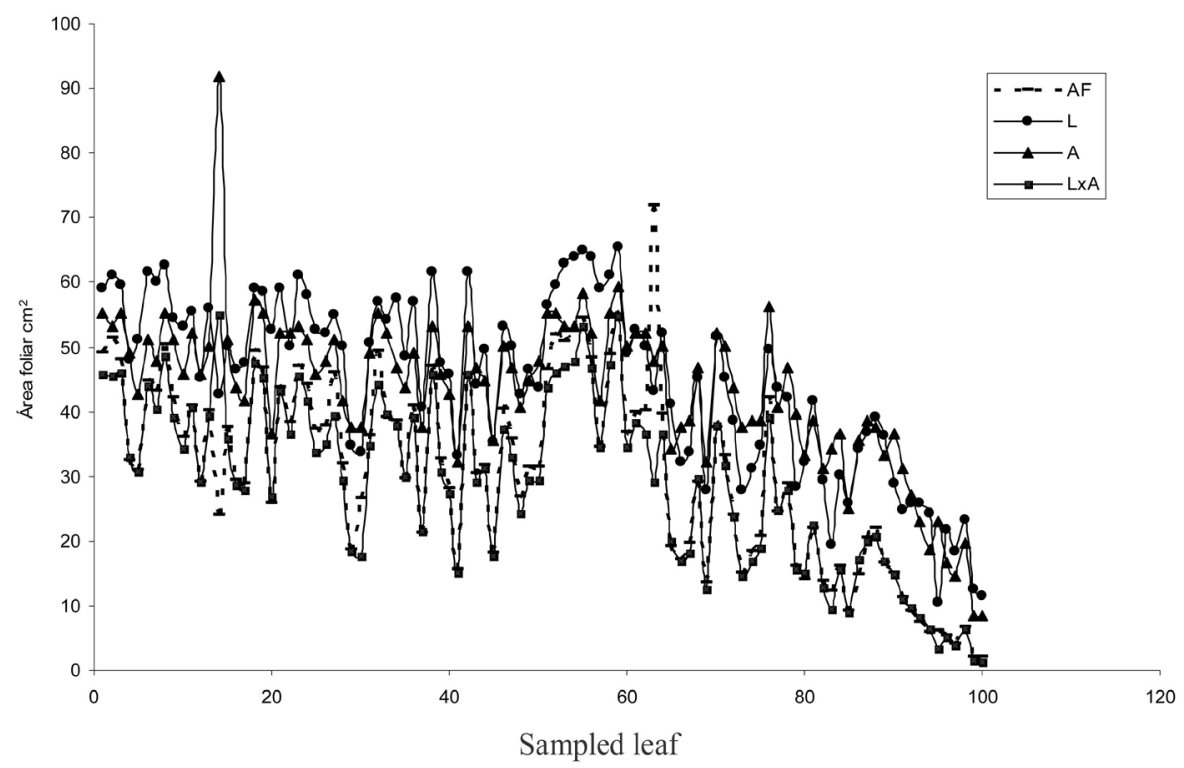

Figure 2. Leaf area integrator obtained with leaf area and simple data calculated length, width and length $\mathrm{X}$ width guava leaves in Iguala, Guerrero. $\mathrm{AF}=$ Leaf area, $\mathrm{L}=$ Length, $\mathrm{A}=$ Width; LXA = Length X Width.

Table 1. Analysis of variance of the mean square error of four variables measured in the leaves of guava cv. "average Chinese".

\begin{tabular}{ccccccc}
\hline Variables & Tree & Rep & Error & Fc & cv & Average \\
AF & 1564.27 & 156.64 & 74.96 & $11.48^{* *}$ & 28.01 & $30.91 \mathrm{~cm}^{2}$ \\
L & 62.07 & 3.85 & 1.86 & $33.34^{* *}$ & 15.04 & $9.07 \mathrm{~cm}^{* *}$ \\
A & 9.56 & 1.06 & 0.46 & $20.97^{* *}$ & 16.14 & $4.18 \mathrm{~cm}^{* *}$ \\
LXA & 2751.63 & 239.53 & 101.34 & $27.15^{* *}$ & 24.82 & $40.55 \mathrm{~cm}^{2}$ \\
GL & 9 & 9 & 81 & & &
\end{tabular}

Rep = Repetition; Fc = F calculated; cv\% = Coefficient of variation; $\mathrm{GL}$ = Degrees of freedom; $\mathrm{AF}$ = Leaf area; $\mathrm{L}$ = Length of leaf; $\mathrm{A}=$ Leaf width; $\mathrm{LXA}=$ length for width; ${ }^{* *}=$ Highly significant. 
long, 10.4234197 for width and length $\mathrm{X}$ width 0.72581647 for). The areas obtained were as follows: In Stage I, which took 15 days, the leaves reached an area of 14,10 and $2 \mathrm{~cm}^{2}$ respectively estimated length, width and length $\mathrm{X}$ width. In Stage II (25 days), the leaf had an estimated area of 55,53 and $39 \mathrm{~cm}^{2}$ based on the length, width and length X width, respectively. Finally, in Stage III (31 days) the estimated values of leaf area were 55, 53 and 43 $\mathrm{cm}^{2}$ when calculated with the length, width and length $\mathrm{X}$ width respectively. I mean, there were differences between the methods in terms of estimated leaf area, so that the product long $\mathrm{X}$ wide, as indicated above, proved to be the most appropriate method for estimating the guava leaf area, which is useful when there isn't an integrating machine offs a leaf area (Figures 3(a)-(c)).

Table 2. Correlation analysis for variables AF, L, A and LXH, of guava leaves, cv. "average Chinese”.

\begin{tabular}{ccccc}
\hline & AF & L & A & LXA \\
\hline AF & \multirow{2}{*}{1.000} & $0.9219^{* *}$ & $0.8172^{* *}$ & $0.9263^{* *}$ \\
& & 0.0001 & 0.0001 & 0.0001 \\
L & & 1.000 & $0.8246^{* *}$ & $0.9566^{* *}$ \\
& & 0.0001 & 0.0001 \\
A & & 1.000 & $0.9232^{* *}$ \\
LXA & & & 0.0001 \\
\hline
\end{tabular}

AF = Leaf area; L = Length of leaf; A = Leaf width; LXA = Length for width; ${ }^{* *}=$ Highly significant.
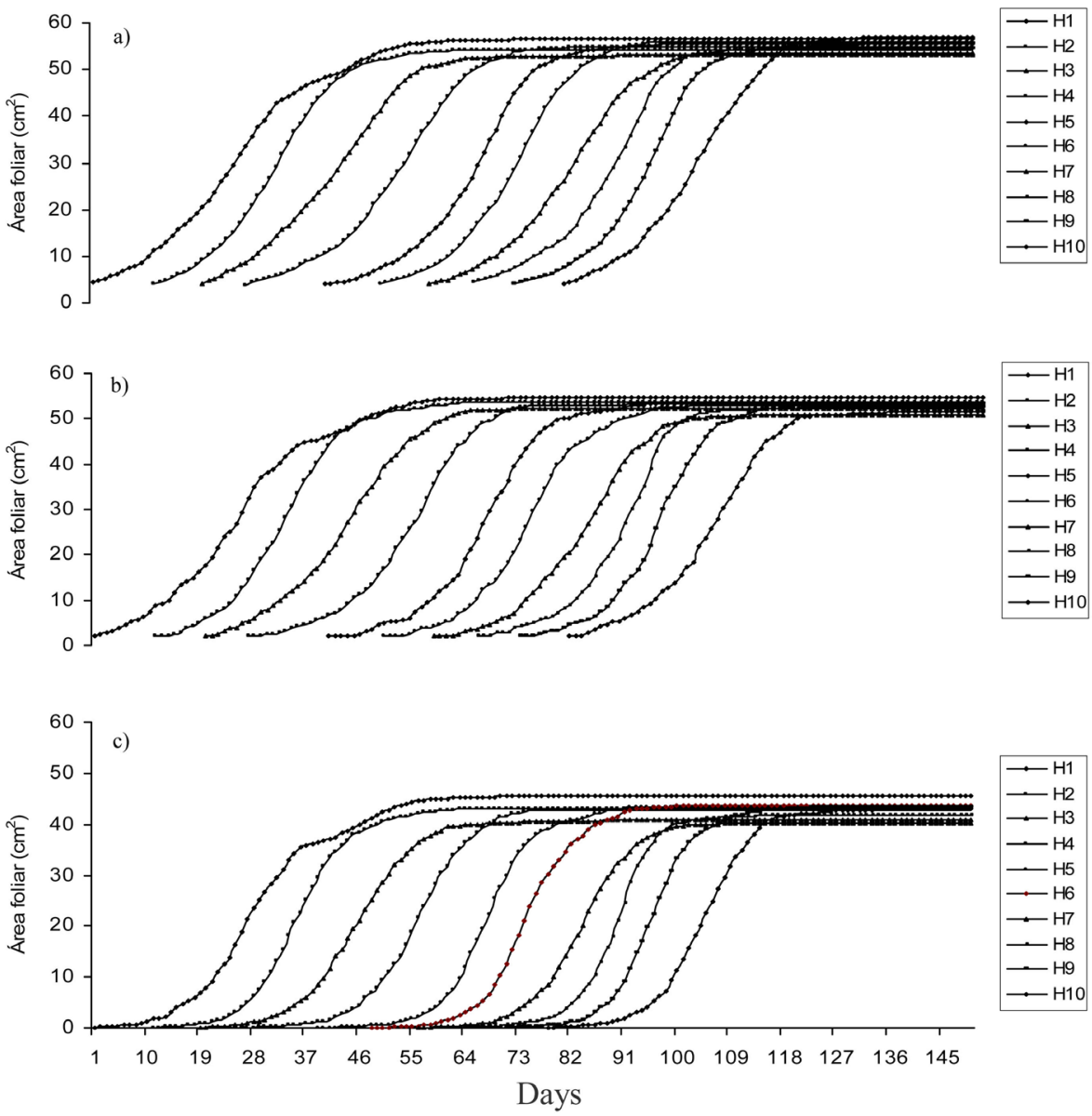

Figure 3. Increased leaf area in $\mathrm{cm}^{2}$, from initial growth to physiological maturity of guava leaf, calculated from a) Length of (4.96351652); b) Width at (10.4234197); and c) Length X Width of (0.72581647) during the period November to May in Iguala, Guerrero. H1, H2 ... $\mathrm{H} 10=$ indicate the sheet number. 


\subsection{Growth Stages of Guava Fruit}

Because the literature has not found the most suitable frequency to record the values of fruit growth, in this research was measured every 1, 5 and 8 days. Found that the journal and the take up every 5 days, showed no significant changes in the size of the result of measurement to another, whereas in the samples measured every 8 days if there were differences between two consecutive, in the equatorial diameter as in the polar. As a result, to obtain the growth kinetics of the fruit is sufficient to measure their size every 8 days. However, daily data allow building a more accurate curve and achieve greater reliability of the kinetics of growth, for more data.

The growth curve of the fruit of guava showed double-sigmoid growth (Figure 4). Stage I showed fast growth and realized the first 61 days (November-January), in which the fruits changed from 0.58 to $2.54 \mathrm{~cm}$ equatorial diameter and 0.66 to $2.97 \mathrm{~cm}$ in diameter polar, at this stage there is a higher division and cell elongation, processes that are responsible for the increased weight and volume of the fruit [11] [12].

Stage II, from 62 to 102 days (January-February), was characterized by slow growth for the fruit barely reached 3.09 and $3.62 \mathrm{~cm}$ equatorial and polar diameter, respectively, the difference in growth compared the first stage was 0.55 and $0.65 \mathrm{~cm}$, respectively. In Stage III, 103 to 126 days (Feb-Mar), was located physiological maturity and fruit
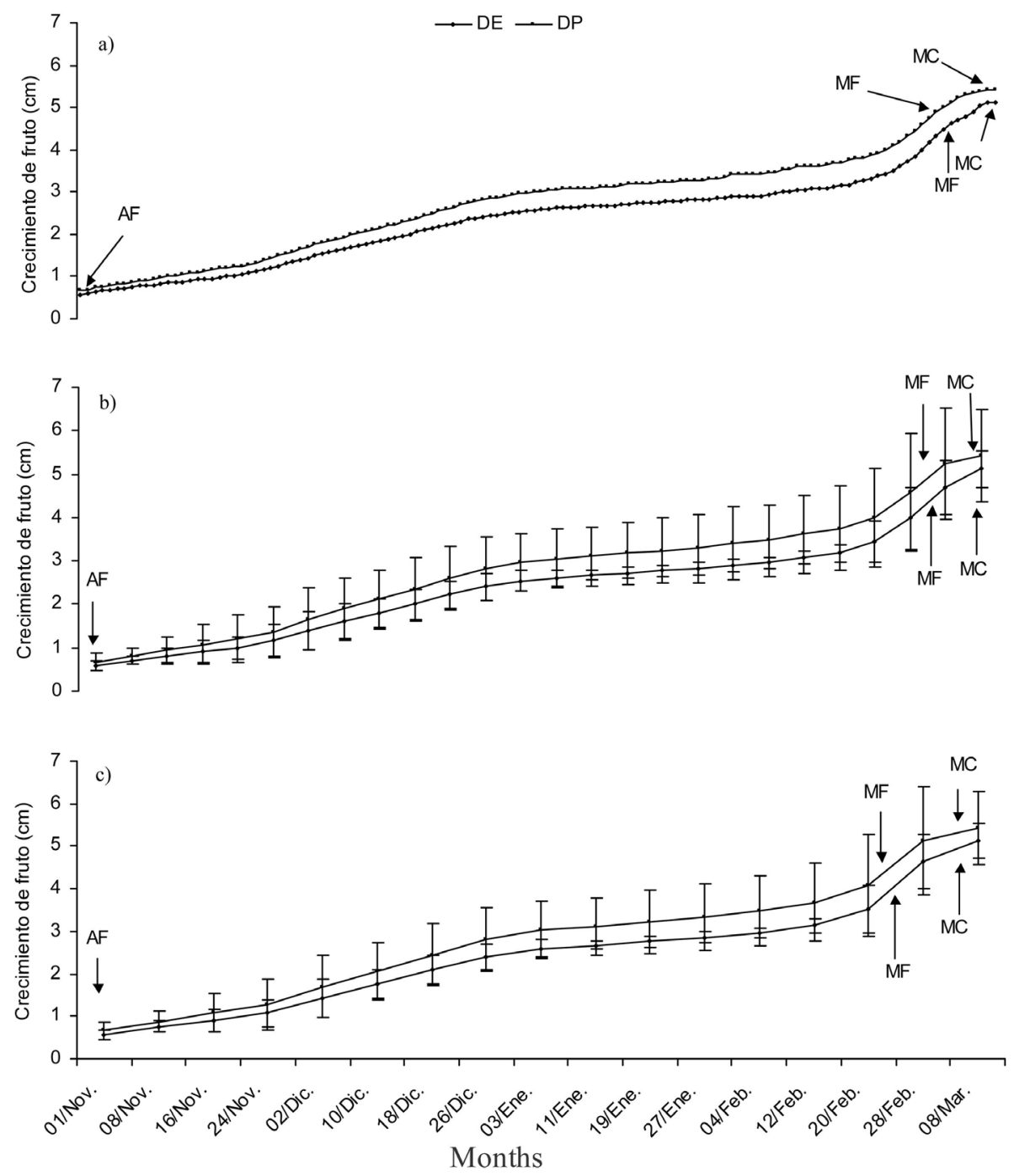

Figure 4. Growth kinetics of guava fruits from tie to trees ripening in 4 years, during November to March, in Iguala, Guerrero. a) Daily Record Data; b) every 5 days; and c) every 8 days. $\mathrm{SD}=$ Diameter equatorial diameter $\mathrm{DP}=$ Polar, $\mathrm{AF}=$ Mooring of fruits, $\mathrm{MF}=$ Physiological maturity, and $\mathrm{MC}=$ Ripe for consumption. Vertical bares indícate standard error. 
consume; until physiological maturity growth was rapid and the fruit reached values of 4.63 and $5.13 \mathrm{~cm}$ in polar and equatorial diameter, at this stage of fruit growth elongation is given by the dependent cellular plasticity and turgor pressure of the cells [13] [14]. After physiological maturity, the fruit continued to grow to maturity in the consumer, when their measures were 5.12 and $5.44 \mathrm{~cm}$ in polar and equatorial diameter, respectively. These values are between the range of sizes of outstanding selections 126, 10, 20, 106 and 103 of the Pavilion Experimental Research of the National Institute for Forestry, Agriculture and Livestock (INIFAP) located in Aguascalientes, Mexico, whose sizes are 4.8 to 6.0 and 5.5 to $6.9 \mathrm{~cm}$ diameter polar and equatorial, respectively [15] and [16].

To reach physiological maturity and consume, this research elapsed 120 and 126 days, respectively. A similar period was reported by Labarca et al. [17], in the plain of Maracaibo, Venezuela to study three materials introduced: Cuban I (127 days), Cuban II (119 days) and Montalban (98 days), the three Psiduium friedrichsthaliamun grafted on. Araujo et al. [4] reported 121 days for the growth of the fruit from the mooring to physiological maturity in guava fruits red Creole type in Maracaibo, Venezuela, while Cañizares [12] indicated that Managas Venezuela the period is 154 days, and Laguado et al. [14] counted 119 days.

The fruit growth rate was 0.032 and 0.038 and 0.013 and $0.015 \mathrm{~cm}$ by day ${ }^{-1}$ in the equatorial and polar diameters, in Stages I and II, respectively, while in the third the rate was 0.085 and 0.084 (physiological maturity) and 0.061 and $0.039 \mathrm{~cm}$ by day ${ }^{-1}$ (ripe), for polar and equatorial diameters, respectively. In the production area of Calvillo, Aguascalientes, Mexico, during Phase I gradually decreases growth of 0.6 to $0.1 \mathrm{~mm} / \mathrm{by} \mathrm{day}^{-1}$; during Phase II growth is below $0.1 \mathrm{~mm} / \mathrm{day}^{-1}$ and III during the growth is increased from 0.1 to $0.9 \mathrm{~mm} /$ day $^{-1}$ [8].

\section{Conclusion}

Leaf area calculated with a length $\mathrm{X}$ width of the leaves, and then multiplied by the respective conversion factor (0.72581647) is similar to that obtained by the integrator leaf area. Leaves showed sigmoid growth and fruit growth double sigmoid type in both cases three steps: for Stage II leaves was the fastest, whereas for fruit was reversed, Stages I and III, were faster compared with Phase II. The time interval between sampling and sampling sufficient to monitor guava fruit growth is eight days.

\section{References}

[1] Padilla, R.J.S., González, G.E., Perales, de la C., Reyes, P.H.R. and Osuna, C.E.S. (2007) Variability of Guava Fruit (Psidium guajava L.) Mexicana. Special Publication Number 1. Experimental Field Pabellón. National Institute of for Research Forest Agricultural and Fisheriest, Pabellón Arteaga.

[2] Martínez-De, Lara.J., Barrientos-Lara, M.C., Reyes-De Anda, A.C., Hernández-Delgado, S., Melilla-Ramírez, J.S., MayekPerez, N. (2004) Phenotypic and Genetic Diversity in Guava Orchards from Calvillo, Aguascalientes. Mexicana Magazine Fitotecnia, 27, 243-249.

[3] Damián, N.A., González, H.V.A., Sánchez, G.P., Peña, V.C.B., Livera, M.N. and Brito, G.T. (2004) Growth and Phenology of Guava (Psidium guajava L.) cv. "Media China” in Iguala, Guerrero. Mexicana Magazine Fitotecnia, 27, 349-358.

[4] Araujo, F., Quintero, S., Salas, J., Villalobos, J. and Casanova, A. (1997) Growth and Nutrient Accumulation Guava Fruit (Psidium guajava L.) Red Creole Type in Maracaibo Plain. Revista de la Facultad de Agronomía (LUZ), 14, 315-328.

[5] Laguado, N., Perez, E., Alvarado, C. and Marin, M. (1999) Physiochemical and Physiological Features Guava Fruits Types of Creole Red and San Miguel at the Mara, Zulia, Venezuela plain. Revista de la Facultad de Agronomía (LUZ), 16, 382-397.

[6] Marin, M.A., Casassa, A., Rincón, J., Labarca, Y., Hernandez, E., Gómez, Z., Viloria, B. and Bracho, J.M. (2000) Agronomy Journal (LUZ), 17, 384-392.

[7] García, E. (1981) Modificaciones al sistema de clasificación climática de Köppen. Universidad Nacional Autónoma de México, México D.F.

[8] Damián, N.A., González, H.V.A., Sánchez, G.P., Peña, V.C.B. and Livera, M.N. (2006) Dynamics and Nutrient Diagnosis of Guava in Iguala, Guerrero, Mexico. Revista Latinoamericana Terra, 24, 125-132.

[9] SAS Institute (1999) SAS Language and Procedure Usage. Version 8, SAS Institute Inc., Cary.

[10] González, G.E., Padilla, R.J.S., Reyes, L.M., Perales, de la C.M.A. and Esquivel, F.V. (2002) Guava; Cultivation in Mexico. Experimental Field Pavilion. National Institute of Forestry, Agriculture and Livestock, Pavilion Aguascalientes. 
[11] Díaz, M.D.H. (2002) Fisiología de Árboles Frutales. AGT Editor, S.A., México D.F., 390 p.

[12] Salisbury, F.B. and Ross, C.W. (1994) Fisiología Vegetal. Grupo Editorial Iberoamérica S.A., México, 759 p.

[13] Cañizares, A., Laverde, D. and Puesme, R. (2003) Growth and Development of Guava (Psidium guajava L.) Fruit in Santa Barbara, Managas State, Venezuela. UDO Agricultural Magazine, 3, 34-38.

[14] Laguado, N., Marín, M., Arenas, de M.L., Araujo, F., Castro, de R.C. and Rincon, A. (2002) Growing Fruit of Guava (Psidium guajava L.) Red Creole Type. Rev. Fac. Agron. (LUZ), 19, 273-283.

[15] Padilla, R.J.S., González, G.E., Muro, R.L., Perales, de la C.M.A., Mercado, S.E.M. and Mayek, P.N. (2003) Caracterización de germoplasma de guayabo en 24 selecciones. En la región de Calvillo-cañones. Aguascalientes. Primer Simposio Internacional de la Guayaba. 8 a 11 de diciembre. Aguascalientes, México.

[16] Perales, de la C.M.A., Padilla, R.J.S., González, G.E. and Reyes, P.H.R. (2005) Manual para la producción integral del cultivo de guayaba. Campo Experimental Pabellón. Instituto Nacional de Investigaciones Forestales Agrícolas y Pecuarias, $175 \mathrm{p}$.

[17] Labarca, E.J., Gómez, E., Hernandez, Y., Rivero, G., Marín, M., Bracho, B. and Cassasa, A. (1999) Fruit Growth of Guava of Three Cuban Introductions Grafted onto Psidium friedrichsthaslisnum Berg-Niedenzum. Rev. Fac. Agron. (LUZ), 16, 382-397. 
Scientific Research Publishing (SCIRP) is one of the largest Open Access journal publishers. It is currently publishing more than 200 open access, online, peer-reviewed journals covering a wide range of academic disciplines. SCIRP serves the worldwide academic communities and contributes to the progress and application of science with its publication.

Other selected journals from SCIRP are listed as below. Submit your manuscript to us via either submit@scirp.org or Online Submission Portal.
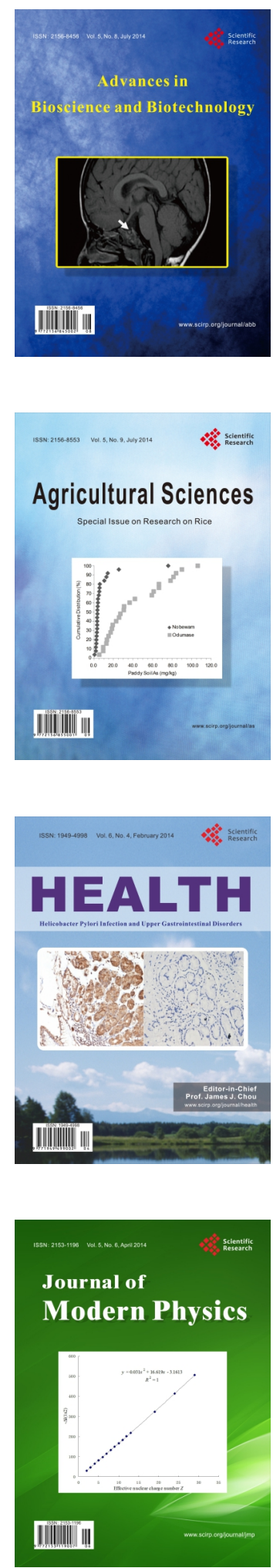
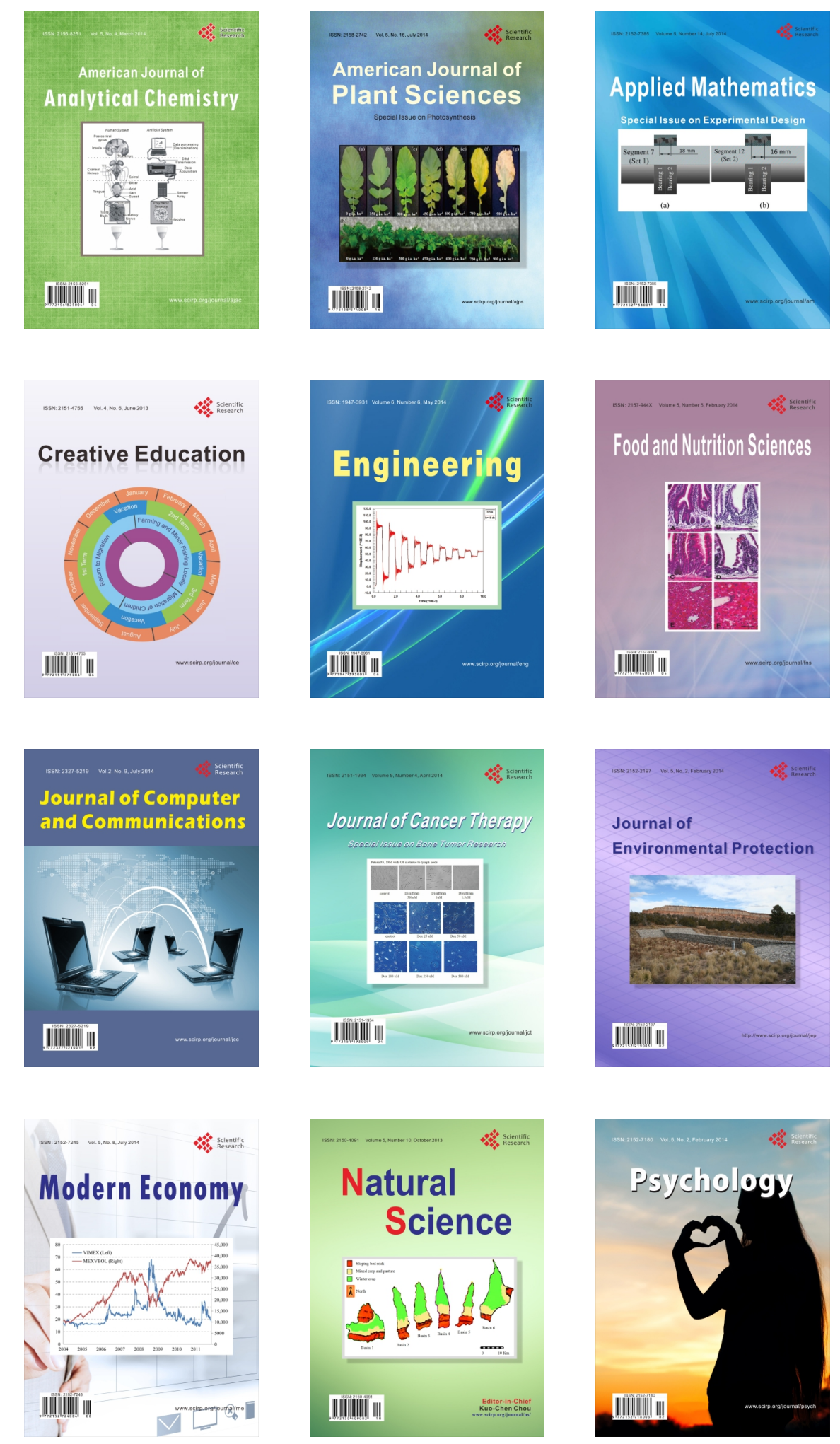